розвитку країни;створити умови для диференційованого навчання тощо.

3. За допомогою зацікавлених міжнародних організацій можливо і необхідно проводити дії, що базуються на наукових даних і на регіональних/національних контекстах, проводити їх моніторинг. Проте для сталого розвитку, нарощування потенціалу інституційного розвитку країн важливим $є$ дійсно міжгалузевий підхід до мобілізації ресурсів і знань учасників міжнародної торгівлі по всьому світу, об'єднання їхніх зусиль.

4. Зміни не тільки у стратегіях, стандартах, але й у самих підходах до розбудови потенціалу будуть поступовими. У національних стратегіях слід передбачити чіткий план довгострокових сталих заходів та практично досяжні завдання на короткотерміновий та проміжні періоди.

5. Реалізація всіма країнами стратегії модернізації на основі розроблених та прийнятих країнами рамкових стандартів сприятиме спрощенню міжнародної торгівлі - одного з найбільш важливих і позитивних досягнень.

\title{
Література
}

1. Павленко О. О. Механізми та інструменти інституційного розвитку митних адміністрацій / О. О. Павленко // Науково-методичний семінар «Упровадження міжнародних стандартів шляхом використання платформи електронного навчання ВМО», Академія митної служби України. - Дніпропетровськ, 2012. 2. Павленко О. О. Формування комунікативної компетенції фахівців митної служби в системі неперервної освіти : дис. докт. пед. наук. 13.00.04 / О.О. Павленко.Дніпропетровськ. - 2010. 3. Рекомендації державної митної служби України до варіативних частин освітньо-професійних програм підготовки магістрів для митної служби / П. В. Пашко, С. В. Гармаш та ін. // Академія митної служби України. Дніпропетровськ, 2010. 4. Buyonge C. East and Southern Africa benefits from new MBA with Customs specialization // WCO News. - October 2011. - № 66. - p. 38-39. 5. PICARD. Professional Standards. - World Customs Organization, Brussels. - 2008. 46 p. 6. Poro A. European Customs training community benefits from new knowledge sharing tool // WCO News. - February 2011. - № 64. - p. 32-33. 7. Widdowson D. Raising the academic standing of the Customs profession // WCO News. - February 2011. - №64. p. 29-30. 8. Reiser B. EU Competency Framework for the Customs profession // PICARD Conference, St. Petersburg, 18-20 September 2013 / EU Commission DG TAXUD / R3. 2013. 9. The WCO Capacity Building Development Compendium/ A Columbus programme phase 2. Implementation tool - World Customs Organization. - 2009. - 188 p. 10. Инструменты эффективного управления // Навчально-методичний посібник [для проведення навчального курсу] / під ред. В. Заложа, Б. Литовченко. - К. : ВАІТЕ, 2012. - 196 с. 11. Учебно-методическое пособие для подготовки тренеровфасилитаторов курса «Инструменты эффективного управления»/ под общ. ред. В. Заложа. - Одесса, 2013. - 126 с.

\section{ІМПЕРАТИВ ГЛОБАЛІЗАЦІЙНИХ ПЕРСПЕКТИВ - ФОРМУВАННЯ ПРОФЕСІЙНО СПРЯМОВАНОГО ІНШОМОВНОГО НАВЧАЛЬНОГО СЕРЕДОВИЩА В УМОВАХ УНІВЕРСИТЕТУ}

Петько Л. В. Імператив глобалізаційних перспектив - формування професійно спрямованого іншомовного навчального середовища в умовах університету.

У статті розглянуто теоретичні та практичні вектори глобальних перспектив України. Визначено роль університету в економічній, соціальній та культурній 
глобалізації, що, у свою чергу, висуває нові імперативи до володіння іноземними мовами професійного спрямування випускниками вищої школи. У зв'язку 3 цим обгрунтовується необхідність формування професійно спрямованого іншомовного навчального середовища в умовах університету.

Ключові слова: економічна глобалізація, соціальна глобалізація, культурна глобалізація, вища освіта, університет, студенти, професійно спрямоване іншомовне навчальне середовище.

Петько Л. В. Императив глобализационных перспектив - формирование профессионально направленной иноязычной среды в условиях университета.

Статья посвящена теоретическим и практическим векторам глобальных перспектив Украины. Рассматривается роль университета в экономической, социальной и культурной глобализации, что, в свою очередь, предъявляет новые императивы к владению иностранными языками профессиональной направленности выпускниками высшей школы, в связи с чем обосновывается необходимость формирования профессионально направленной иноязычной среды в условиях университета.

Ключевые слова: экономическая глобализация, социальная глобализация, культурная глобализация, высшее образование, университет, студенты, профессионально направленная иноязычная среда.

Pet'ko L. V. The imperative of globalization perspectives - the formation of the professionally oriented foreign language educational environment in the conditions of university.

The article reveals theoretical and practical aspects of global perspectives of Ukraine.It examines the role of the university in economical, social and cultural globalization, whichin its turn sets new imperatives of University graduates' foreign language mastering in professional field. In this context the necessity of professionally-oriented foreign language environment in terms of university is proved.

Key words: economic globalization, social globalization, cultural globalization, higher education, university, students, professionally oriented foreign language environment.

Вітчизняні науковці визначають економічний розвиток України в XXI ст. під упливом техноглобалізму, що унеможливлює існування країни в технологічному вакуумі, без розвитку власної науково-технологічної індустрії, використання кращих світових надбань у цій галузі. Пріоритет надається «динамічному освоєнню базових технологій і виробництв шостого технологічного укладу, які відкривають широкі можливості щодо приєднання до чергової хвилі економічного зростання» [1, с. 312].

Глобаліза́ція (англ. globalization) - процес всесвітньої економічної, політичної та культурноїінтеграції та уніфікації, який розглядається якпланетарне явище, основними наслідками якого $є$ міжнародний поділ праці, міграція в масштабах усієї планети капіталу, людських та виробничих ресурсів, стандартизація законодавства, економічних та технічних процесів, зближення культур різних країн [3].

Виходячи 3 наукових позицій дослідників, для досягнення стратегічної мети в розвитку України пропонуються такі першочергові заходи: 1) виокремлення як національного пріоритету сектору інноваційного виробництва (Україна потребує масштабного розгортання стратегії технологічного прориву і програми іiі реалізації; в умовах жорстокої конкуренції акценти розставляються на здатності створення й ефективному використанні передових технологій, які розглядаються як форма реалізації науково-технічних знань; 2) підвищення індексу технологічного розвитку (відбудеться за умов політики відкритості та залучення зарубіжного науково- 
технологічного потенціалу); 3 ) розроблення конкретних механізмів адаптації України до глобальних процесів технологічної інтеграції (стимулювання розвитку інноваційної діяльності, розвинена система науки та освіти, різноманітні форми міжнародного науково-технічного i технологічного співробітництва (технопарки, спільні науково-технічні проекти, програми тощо); 4) інтернаціоналізація і трансфер технологій (розглядається як умова формування економіки знань); 5) стратегія сприяння розвитку міжнародного науково-технологічного співтовариства; 6) розвиток зв’язків зі світом високих технологій [1, с. 312-314].

Отже, маючи відносно достовірну інформацію щодо шляхів розвитку України у третьому тисячолітті, можна констатувати, що такий напрямок буде забезпечений завдяки інноваційній освіті, яка слугуватиме підготовці фахівця нового типу, а вивчення іноземних мов посідатиме одне з пріоритетних місць.

Навчання іноземної мови у вищій школі зорієнтовано на створення такого професійно спрямованого іншомовного середовища, яке за мету визначає не тільки здатність до міжкультурного спілкування, а й формування в майбутніх випускників університетів умінь і навичок професійного використання іноземної мови у своїй подальшій професійній кар'єрі.

Низка останніх оприлюднених державних документів - Указ Президента України «Про національну стратегію розвитку освіти в Україні на період до 2021 р.» (2013 р.) [6], Державна цільова науково-технічна та соціальна програма «Наука в університетах» на 2008-2017 pр.» [11], наказ МОН «Щодо затвердження Примірного положення про академічну мобільність студентів вищих навчальних закладів України» (2013р.) [10], прийняття Педагогічної Конституції Свропи (2013 р., Німеччина) [7], а також Рекомендації МОП/ЮНЕСКО (стосовно статусу учителів, 1966) [20], Рекомендації ЮНЕСКО (стосовно статусу викладацьких кадрів вищих навчальних закладів, 1997 р.) [12], Лісабонські домовленості (визнання кваліфікацій у галузі вищої освіти, 1997) [22], Міжнародна стандартна класифікація освіти (МСКО, 2011) [5] окреслюють інтеграцію вітчизняних університетів до європейського науково-освітньогопростору передбачають перегляд змісту освіти, педагогічної зокрема, створення в Україні конкурентоспроможної системи генерування знань у контексті викликів глобалізаційних перспектив, а це вимагає від педагогічної освіти «визначення принципів моделювання стратегій навчання, стратегічне навчання, дослідницька комунікативна стратегія навчання, лідерство вчителя як його потенційно сильна стратегія навчання» [7], де опорою сучасної освітньої стратегії та нових стандартів розглядають технології та іноземну мову.

Характеризуючи вплив глобалізації у кожній галузі суспільства, виокремлюють такий комплекс проблем у соціальній галузі: динаміка багатства і бідності, проблема нерівності, безробіття, неконтрольована міграція, «викачка мізків», демографічні та екологічні проблеми. Водночас гостро стали виявлятися негаразди в культурному вимірі: проблеми культурної, релігійної і національної ідентичності, проблема віртуалізації, уніфікація (ііі наслідки як масовізація і соціокультурна шаблонізація) [9].

Задля виявлення та вивчення глобалізаційних тенденцій серед 208 країн світу за 2012 р., ми дослідили показники першої десятки, а також США, України, Росії, Японії, Китаю та Польщі за інтегральним глобалізаційним індексом (ГІ), індексом економічної глобалізації (ЕГ; економічні потоки, економічні обмеження, обсяги міжнародної торгівлі, прямі іноземні інвестиції, торговельні обмеження), індексом соціальної глобалізації (СГ; культурна комунікація, міжнародний туризм, показники персональних контактів (комунікація): телефонний трафік, індивідуальні трансфери, 
міжнародне листування, інформаційні потоки, інформаційно-комунікаційні технології (користувачі Інтернетом, доступ до телебачення, газет), індексом політичної глобалізації (ПГ; кількість укладених міжнародних угод, чисельність іноземних посольств (представництв) у країні).

Як представлено на таблиці 1, у першій десятці глобалізаційного індексу перебувають європейські країни, тільки Сінгапур посідає 5 місце. В індексі економічної глобалізації пріоритет знову належить європейським державам (7 країн), але на перше місце вийшов Сінгапур, на 9 та 10 місцях опинилися країни Перської затоки: Бахрейн та ОАЕ (зрозуміло, що це пов'язано 3 видобутком нафти, розгортанням транснаціональних компаній). Показники індексу соціальної глобалізації засвідчують перевагу країн Свропи (8 країн), хоча Сінгапур посів 3 місце, а Канада - 7 місце.

Таблиця 1

Показники інтегрального глобалізаційного індексу КОF серед країн світу за 2012 р.

\begin{tabular}{|c|c|c|c|c|c|c|c|c|}
\hline Місце & Країна & $\Gamma \mathbf{I}$ & Країна & $\mathbf{E \Gamma}$ & Країна & $\mathbf{C \Gamma}$ & Країна & ПГГ \\
\hline 1 & Бельгія & 2,76 & Сінгапур & 7,39 & Кіпр & 1,76 & Італія & 8,43 \\
\hline 2 & Ірландія & 1,95 & Люксембург & 4,63 & Ірландія & 1,43 & Франція & 8,24 \\
\hline 3. & Нідерланди & 0,94 & Ірландія & 3,27 & Сінгапур & 1,4 & Бельгія & 7,91 \\
\hline 4. & Австрія & 0,55 & Мальта & 2,23 & Австрія & 8,28 & Австрія & 7,31 \\
\hline 5. & Сінгапур & 9,18 & Бельгія & 2,15 & Бельгія & 89,75 & Іспанія & 96,68 \\
\hline 6. & Швеція & 8,23 & Нідерланди & 1,91 & Швейцарія & 89,43 & В.Британія & 96,43 \\
\hline 7. & Данія & 88,11 & Угорщина & 0,50 & Канада & 8,72 & Швеція & 5,86 \\
\hline 8. & Угорщина & 87,38 & Швеція & 8,98 & Нідерланди & 7,87 & Польща & 5,17 \\
\hline 9. & Португалія & 86,73 & Бахрейн & 8,96 & Данія & 6,19 & Португалія & 4,36 \\
\hline 10. & Швейцарія & 86,64 & OAE & 8,74 & Франція & 5,65 & Канада & 4,16 \\
\hline 26. & Польща & 79,10 & 44 місце & 2,78 & 26 місце & 7,02 & 26 місце & 0,82 \\
\hline 35 & США & 74,88 & 79 місце & 0,83 & 29 місце & 6,24 & 22 місце & 2,47 \\
\hline 44. & Україна & 68,48 & 61 місце & 7,39 & 69 місце & 7,02 & 43 місце & 6,33 \\
\hline 47. & Росія & 67,35 & 98 місце & 4,56 & 46 місце & 6,96 & 46 місце & 5,69 \\
\hline 55. & Японія & 64,13 & 120 місце & 45,84 & 51 місце & 4,57 & 33 місце & 8,91 \\
\hline 73. & Китай & 59,37 & 107 місце & 51,25 & 93 місце & 8,09 & 41 місце & 6,70 \\
\hline
\end{tabular}

Джерело: побудовано за: KOF Index of Globalization [Електронний ресурс]. - Режим доступу: http://globalization.kof.ethz.ch/ [20]

Нарешті, індекс політичної глобалізації показав також лідерство європейських країн (8), тоді як Канада посіла 10 місце.

Привертають увагу показники Польщі, України, Росії, Японії та Китаю, серед яких Польща - лідер. За індексом соціальної глобалізації Україна посідає 69 місце, а ПГ - 43 місце.

Наведені вище результати аналізу динаміки індексу глобалізації (щільність, упорядкованість, структурованість показників) дозволяють говорити про системний характер глобалізаційного процесу і пріоритетність європейського вектору економікосоціально-політичного індексів глобалізації.

Хоча треба додати, що сучасне технологічне «ядро» глобальної економіки становить вузьке коло країн (Японія, США, ФРН, Великобританія, Франція), які володіють 46 макротехнологіями 3 50, що забезпечують світове виробництво високотехнологічної продукції. Також вони контролюють близько $80 \%$ світового ринку високих технологій, де США $є$ монополістом, а саме: США - 20-22 макротехнологій, Німеччина - 8-10, Японія - 7, Великобританія та Франція - 3-5, на 
Швецію, Італію, Швейцірію, Норвегію припадає по 1-2 [15, с. 6].

Питання аналізу й оцінки впливу техноглобалізму на модифікацію економічного циклу знайшли своє відображення в науковому доробку А. Поручника, Л. Антонюк [1, с. 125]. Науковці з'ясували, що колосальна частка світових винаходів сконцентрована у 12 найбільш технологічно розвинутих країнах світу, завдяки проведенню ними ефективної інтеграції фундаментальної та прикладної науки, також вони зосередили світовий фінансовий, технологічний, кадровий та інтелектуальні ресурси, монополізували права на володіння ними. Варто підкреслити той факт, що із загальної кількості патентів, які щорічно реєструються в Бюро патентів і торговельних марок США (U.S. Patent and Trademark Office, USPTO), американським представникам належить близько $60 \%$ (із загальної кількості), японським - 25\%, німецьким - 10\%, французьким - 5\%.

3 огляду на викладене актуальним постає мовне питання, тому що багатомовність стала ознакою i суттю Європи. До того ж, англійська мова розглядається вже не як іноземна, а як міжнародна мова, чому активно слугують глобалізаційні процеси, а виникнення комп'ютеризації та Інтернету недосяжно для інших мов поширило англійську в мовно-інформативному просторі (біля 90\% всієї інформації в Інтернеті подається англійською мовою), незнання якої стає перепоною для перспектив майбутнього спеціаліста.

Якість професійної підготовки фахівців різних спеціальностей, педагогів зокрема, $\epsilon$ важливим завданням державної освітньої політики, розв'язання якого набуває своєї гостроти в сучасному глобалізаційному процесі та визначеним Україною курсом на євроінтеграцію. Процес підготовки вчителя - довготривалий, основи якого закладаються в університеті.

Маючи достатній досвід педагогічної роботи, ми виокремили такі проблеми і суперечності щодо формування професійно спрямованого іншомовного навчального середовища в умовах університету: 1) традиційною системою викладання іноземної мови (IM) у відриві від професійно спрямованого навчального середовища в умовах університету; 2) потребами суспільства та особистості студента в переході до діяльнісного методу навчання, функціонально-цільового підходу і реальною підготовкою до професійної педагогічної діяльності в певному соціумі; 3) наявною у практиці педагогічного університету усталеною системою підготовки студентів засобами іншомовної освіти та особистісно розвивальним характером навчання IM; 4) організацією навчання IM студентів у відриві від психолого-педагогічних дисциплін, фахових методик i необхідністю реалізації міждисциплінарних зв'язків задля покращення якості навчання IM; 5) створення інтегрованих навчальних планів; 6) усвідомленням студентами необхідності i значущості розвитку іншомовної професійної компетентноссті і недостатнім рівнем іiі сформованості; 7) розроблення цілісної системи роботи $з$ талановитими студентами, формування їхнього наукового та професійного зростання; 8) неготовність викладацького корпусу до інноваційної діяльності.

3-поміж основних чинників, що впливають на формування позитивної мотивації до оволодіння іноземною мовою у студентів немовних ВНЗ, виокремлюють такі: 1) зміст навчального матеріалу; 2) організація навчальної діяльності; 3 ) застосування комунікативного підходу до навчання іноземної мови; 4) застосування інформаційнокомунікаційних технологій під час навчання іноземної мови; 5) стиль педагогічної діяльності педагога (інтелектуальна мобільність, комунікабельність, позитивне сприйняття нового, готовність до професійного й особистісного зростання) [8, с. 244-245]. 
Тому створення професійно спрямованого іншомовного навчального середовища в умовах вищої школи постає актуальною проблемою сьогодення і повинно бути зорієнтоване на формування у студентів лінгвосоціокультурної компетенції, яка передбачає соціолінгвістичну, соціокультурну, соціальну компетенції.

Як слушно наголошує Ю. Юринець, у другій половині ХХст. «назріла необхідність, у контексті нових суспільно-політичних і соціогуманітарних реалій, проведення системних освітніх реформ у багатьох країнах світу, розгортання активних процесів інтернаціоналізації й міжнародної кооперації в галузі вищої освіти, нагадати Європі про історичну місію університетів, актуалізувати вікові цінності та традиції університетської освіти, що і спричинило прийняття Великої Хартії Європейських Університетів» [16, с. 102], 25-річчя якої святкували у вересні 2013 р. у стінах Болонського університету (Італія).

Слід також узяти до уваги, що серед університетів Європи та світу найбільше представництво у Великій хартії університетів має Італія - 50, Іспанія - 39, Велика Британія - 32, Німеччина - 30, Україна - 30, Польща - 23, США - 21, Туреччина - 20, Казахстан - 18, Росія - 12, Грузія - 4,Вірменія, Азербайджан, Молдова, Туркменістан - по 1 університету. Таке чисельне приєднання університетів України до Великої хартії університетів свідчить про прагнення до творчої колективної діяльності у світовому університетському співтоваристві [19].

У Преамбулі Великої Хартії Європейських Університетів (1988) наголошується, що майбутнє людства значною мірою залежить від культурного, наукового i технічного розвитку, зосередженого в центрах культури, знання $і$ досліджень, якими $\epsilon$ справжні університети, а завдання університетів щодо поширення знань серед нових поколінь передбачає, що в нинішньому світі вони також повинні служити суспільству в цілому і що культурне, соціальне й економічне майбутнє суспільства вимагає, зокрема, значного внеску в подальшу освіту [2].

Звертаючись до розгляду ролі глобалізації, П. Скотт зазначає, що остання актуалізує університети в поширенні національних культур, сприяє стандартизації навчання, обмежує бюджетні можливості розвинених країн [13, с. 3-4].

Водночас В. Тітарчук акцентує увагу на тому, що культурна глобалізація вищої освіти $\epsilon$ нерівномірним, суперечливим і складним явищем. Розглядаючи теоретичний інструментарій аналізу цього феномена, очевидним стає факт, що глобалізація вищої освіти веде до якісно іншого утворення - «космополітичного» університету, побудованого на культурних цінностях західного світу. Автор наголошує, що скористатися перевагами цього процесу зможуть лише країни євроатлантичної цивілізації з певним набором соціокультурних характеристик.

Виходячи 3 цього, дослідниця визначила такі наслідки для культурної глобалізації української вищої школи: 1) популяризація глобальних мультикультурних цінностей; 2) посилення світового домінування євроатлантичної культури; 3) поява зарубіжних освітніх провайдерів на територіях національних держав; 4) втрата національної культури та ідентичності [14, с. 3-4].

У свою чергу Інститут статистики ЮНЕСКО [4], будучи провідним центром 3 міжнародних статистичних даних у галузі освіти (охоплює понад 200 країн), розробив МСКО задля впорядковування освітніх програм та відповідних кваліфікацій за рівнями та галузям освіти.

Ми вивчили зміст програм вступних випробувань до магістратури у 2013 р. в Україні та в інших країнах СНГ. Якщо вступники українських вишів обов'язково повинні складати вступне випробування до магістратури 3 іноземної мови за 
професійним спрямуванням (згідно з вимогами Концепції організації та підготовки магістрів в Україні (2009), то в Білорусії, Росії іноземну мову за професійним спрямуванням вступники до магістратури не складають, тоді як у Казахстані, крім державної мови, складається іноземна та російська мови, в Азербайджані (крім профільного комплексного іспиту) перевіряється інтелектуальний рівень вступника (логічне мислення), знання з інформатики та іноземної мови.

При цьому треба врахувати, що США перетворили національну систему освіти не тільки на знаряддя культурного впливу, а й на досить успішний бізнес-проект (популярність здобуття освіти в США та престижність диплому). Статистика свідчить: щорокув США отримують освіту близько 650 тис. іноземних студентів (1/3 загальноосвітнього показника), тоді як у Великобританії навчається біля 270 тис. іноземних студентів (університети та коледжі), у Франції- 120 тис. іноземних студентів, у свою чергу, Японія планує залучити до навчання до 130 тис. іноземних студентів [1, с. 135].

3 огляду на вищезазначене сучасні підходи до освіти вимагають переосмислення сутності та завдань навчання іноземної мови в умовах вищої школи, тоді як передавання знань від викладача до студента не є досить ефективною у процесі їхньої професійної підготовки. Якісна професійна підготовка майбутніх випускників вищої школи передбачає оволодіння грунтовними базовими знаннями, комунікативними вміннями, навичками іншомовного спілкуванняза професійним спрямуванням.

Особливої уваги набуває проблема мовленнєвотворчої діяльності, що передбачає володіння студентами різними формами роботи над мовним матеріалом з орієнтацією на майбутню професію, отримання глибоких знань 3 іноземної мови завдяки вміло організованому та сформованому професійно спрямованому іншомовному навчальному середовищу в умовах університету.

Підсумовуючи викладене, зазначимо, що відповідно до показників інтегрального глобалізаційного індексу, індексу економічної глобалізації, індексу соціальної глобалізації, індексу політичної глобалізації Україна посіла серед 208 країн світу відповідно 44 місце, 61 місце, 69 місце та 43 місце. (табл. 1.), що свідчить про активні глобалізаційні перспективи нашої держави.

При цьому слід ураховувати й те, що процес входження України до європейського культурного та освітнього простору характеризується зростанням ролі вивчення іноземної мови (передусім - англійської, французької, німецької, іспанської) у процесі підготовки кваліфікованих фахівців. Здатність спілкуватися іноземною мовою, орієнтуватися в глобальному інформаційному просторі та використовувати іiі в майбутній професійній діяльності стала імперативом сьогодення, необхідним складником підготовки спеціаліста в умовах університету.

\section{Література}

1. Антициклічне регулювання ринкової економіки: глобалізаційна перспектива: [монографія] / Д. Г. Лук’яненко, А. М. Поручник, Я. М. Столярчук [та ін.]; за заг. ред. Д. Г. Лук'яненка, А. М. Поручника. - К. : КНЕУ, 2010. - 334 с. 2. Велика Хартія Европейських Університетів (Болонья, 18.09.1988)[Электронный ресурс]. - Режим доступа: http://www.Inu.edu.ua/Pedagogika/bolon/02.pdf 3. Глобалізація[Электронный ресурс]. -

Режим

доступа:http://uk.wikipedia.org/wiki/\%D0\%93\%D\%D0\%B1\%D0\%B04. Інститут статистики ЮНЕСКО [Електронний ресурс].- Режим доступа: http://www.uis. unesco.org/ Education/Pages/ default.aspx. 5. Міжнародна стандартна класифікація освіти (2011р.) [Електронний ресурс]. - Режим доступа :http://www.uis.unesco.org/ 
Education/Documents/UNESCO_GC_36C-19_ISCED_RU.pdf 6. Національна стратегія розвитку освіти в Україні на 2012-2021// Директор школи, ліцею, гімназії : наук.практ. журн. / засн. М-во освіти і науки України ; голов. ред. О. І. Виговська. - К., 2011 - № 6. - С. 25-44. 7. Педагогічна Конституція Європи [Електронний ресурс]. Режим доступу: http://www.arpue.org/index.php/ru/hlavnaia/104-pedagogicheskayakonstitutsiya-evropy/141-pedahohichna-konstytutsiia-yevropy-1

8. Побережна $\mathbf{H}$. Професійна мотивація та іiї роль у формуванні мотивації до вивчення іноземних мов у студентів немовних ВНЗ / Н. Побережна // Педагогіка вищої та середньої школи: зб. наук. праць. - Кривий Ріг, 2013. - Вип. 38. - С. 242-246. 9. Подольська Є. А. Соціологія. 100 питань. 100 відповідей: електронний підручник для студентів ВНЗ / Є. А. Подольська, Т. В. Подольська - 2009. - Ч. 4. Сучасна цивілізація і соціальні трансформації [Електронний ресурс]. - Режим доступу :http:/pidruchniki.ws/ 15840720/sotsiologiya/sotsiologiya_100_pitan_100_vidpovidey_-_podolska_yea

10. Примірне положення про академічну мобільність студентів вищих навчальних закладів України/ Наказ Міністерства освіти і науки України від 29.05.2013 № 635[Електронний ресурс]. - Режим доступу :http:/guonkh.gov.ua/ normative/ nakazi_monu/5129.html 11. Про затвердження Державної цільової науково-технічної та соціальної програми «Наука в університетах» на 2008-2017 роки / Постанова Кабінету Міністрів від 19.09.2007 № 1155 [Електронний ресурс]. - Режим доступу :http://zakon4.rada.gov.ua/laws/show/1155-2007-\%D0\%BF 12. Рекомендация о статусе преподавательских кадров высших учебных заведений: Рекомендация МОТ и ЮНЕСКО (Париж, 21.10.1997 г.)/ Публ.: Центр образовательного законодательства[Электронный ресурс].- Режим доступа: http://www.lexed.ru/doc.php?id=3890\# 13. Скотт П. Глобализация и университет / П.Скотт // ВВШ «Alma Mater». - 2000. - № 4. - С. 3-8. 14. Тітарчук В. Соціокультурна глобалізація вищої освіти: тенденції та наслідки/ В. Титарчук// Віче. - 2006.- $\quad$ № 22[Електронний $\quad$ ресурс]. доступу :http://www.viche.info/journal/391/15. Федулова Л. Технологічний розвиток економіки /Л.Федулова //Економіка України. - 2006. - № 6. - С. 6 . 16. Юринець Ю. Л.Рекомендації ЮНЕСКО щодо академічних свобод / Ю. Л. Юринець // Часопис Академії адвокатури України. - 11(2’2011). - С. 1-5. 17. Kluver Randy. Measuring cultural globalization / Randy Kluver, Fu Wayne. - Nanyang Technological University, Singapore : mimeo, 2004. 18. KOF Index of Globalization [Web site]. - Access mode :http://globalization.kof.ethz.ch/media/filer_ public/2013/03/25/ definitions_2013.pdf 19. Magna Charta Universitetum - Велика хартія університетів[Web site]. - Access mode :http://virtuni.education.zp.ua/info_cpu/node/1220 20. Recommendation concerning the Status of Teachers / The Resolutions adopted by the Conference and the Reports of the Commissions of the fourteenth session of the General Conference of UNESCO. - UNESCO, 1967. - P. 29-40. 21. Rosendorf Neal M. Social and Cultural Globalization: Concepts, History, and America’s Role, in: Joseph S. Nye and John D. Donahue (eds.) / Neal M. Rosendorf // Governance in a Globalizing World, Brookings Institution Press, Washington D. C., 2000. - p. 109-134. 22. The Lisbon Recognition Convention, 1997. The Convention on the Recognition of Qualifications concerning Higher Education in the European Region[Web site]. - Access mode: http://www.cicic.ca/697/lisbonconvention.canada.

\section{ПЕДАГОГІЧНА МАЙСТЕРНІСТЬ ВИКЛАДАЧІВ ІНОЗЕМНОЇ МОВИ}

